\title{
無縫合血管吻合法による血管移植術
}

\author{
Microballoon catheter 老用いて
}

畑中 光昭 - 岩㴊隆

\section{Nonsuture Small Vessel Replacement Using Microballoon Catheter}

\author{
Mitsuaki HATANAKA and Takashi IWABUCHI \\ Department of Neurosurgery, Hirosaki University, Aomori
}

\begin{abstract}
A nonsuture anastomotic method for small vascular replacement using a microballoon catheter and plastic adhesive was devised. Various-sized balloon catheters $(0.4-2.0 \mathrm{~mm}$ in external diameters) were made of latex balloons and polyethylene tube. Both ends of a balloon were fixed to the polyethylene tube so that the size and shape could be controlled more easily than in free-end balloon catheters. Alpha-ethylcyanoacrylate monomer, a plastic adhesive, was used instead of suture. Eleven common carotid and femoral arteries of dogs were used for end-to-end arterial anastomosis by this method. Nine femoral or saphenous veins were used as autogenous vein grafts and eleven expanded polytetrafluoroethylene (EPTFE) grafts as artificial grafts. In follow up studies from 2 days to 6 months, the patency rate of endto-end arterial anastomosis, end-to-end vein grafting, and end-to-end artificial grafting were $90.9 \%$, $88.9 \%$, and $66.7 \%$, respectively. It took about 5 minutes for end-to-end arterial anastomosis and about 10 to 15 minutes for vascular replacement. One or two stay sutures were used effectively in autogenous vein grafting. The advantages of this method were good and free control of the vascular caliber and shape during vascular anastomosis and a diminishment of endothelial damage. Clinical application of this method of vascular replacement is expected in the near future.
\end{abstract}

Key words: microsurgery, vascular anastomosis, vascular replacement, balloon catheter, expanded polytetrafluoroethylene

\section{I はじめに}

脳神経外科領域に括讨る血管吻合術法，浅側頭一中大脳 動脈吻合術を中心に発展してきたが，最近では自家静脈

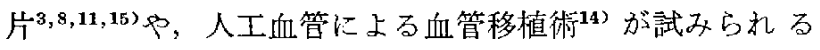
ようになり，手術操作の簡便化，操作時間の短縮や，深部 に打ける狭い術野ての操作が 60 , 13,17,21)いっそら要求される よ5になってきた。その対策の一謤として, 種々の無縫合 血管吻合法 $4,6,7,10,12,19-21$ 'が研究され，我々も可溶性支柱と 生体接着剂を用いた無縫合血管吻合法を開拓 $\mathrm{L}^{6,17}$ ，外径 $1 \mathrm{~mm}$ 前後の血管にも応用でき5,21)，可溶性支柱を用いて
の実験的小静脈片移植術を試みてきた。しかし，可溶性支 柱の使用には，軽度ながら内腔面の擦稘，操作中の溶解縮 小に上る吻合口径の狭小などの短所があり，口径差を有 する血管同志の吻合，特に伸縮の大きな静脈片などでは若 干を残している，我々はこれら血管移植術を円滑にする目 的で，吻合部の内腔定自由，かつ円滑に調節できる micro-

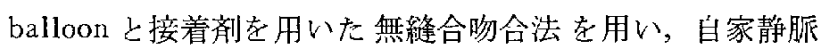
片执よび EPTFE (Goretex) の実験的血管移植刭を行い, 良好な結果を得た。今回は端々吻合法を中心に報告才る。

弘前大学脳神経外科

Address reprint requests to: M. Hatanaka M. D., Department of Neurological Surgery, Towada City Hospital, 14-8 Nishi 12 ban-cho, Towada, Aomori 034 .

受稿 1982年 4 月27日 受理 1982年 9 月 2 日 


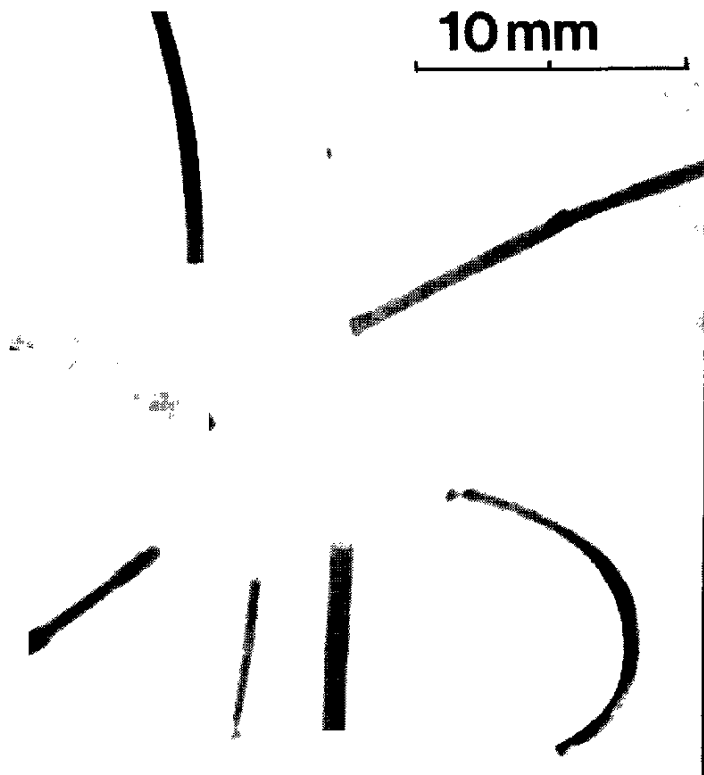

A

Fig. 1 A: Various sized latex tubes for the balloon catheter. latex and polyethylene tube (left).

\section{II 方 法}

雑種成犬 $(5 \sim 8 \mathrm{~kg}) 21$ 頭を用い, (1)総頸動脈また法大腿 動脈を用いた動脈端々吻合術, (2)大腿静脈または大伏在静 脈孛自家静脈片とした総頚動脈一の静脈移植術，さらに， (3)内径 $3 \mathrm{~mm}$ の EPTFE graft 它用いた総頚動脈への人工 血管移植術を行った。吻合部の血管内腔保持のためには， $2 \sim 5 \mathrm{~F}$ の動脈塞栓除去用 Fogarty catheter 抒よび polyethylenc，または teflon tube $の$ 先端に latex 製 microballoon を取り付け，両端を固定した balloon catheter を作製して 用いた(Fig. 1)。接着郕としては alpha-ethyl-cyanoacrylatc monomer 老用い，操作は寸べて手術用顕微鏡を用いて行 った.

\section{1. 動脈端々吻合術}

ペントバルビタールの静脈麻酔下に䫓部正中切開を加 え, 総頸動脈安遊颜露出した。血流を一時遮断し, 動脈切 溯, 外膜剝離切除後, 内腔洗滌を行った。切断端より約 10 $\mathrm{mm}$ 中枢側に0.5 mm の小孔を開活, balloon catheter 吻 合部まで挿入した。次に血管の吻合部両端を等せ合わせ， balloon 内に生食水を注入して，血流流通時の口径走超 るまで balloon 索膨胀させ，雨血管端を密着接合させた。 内翻や間隙のないこと至確認の上，直接，可及的に薄く接 着剂塗布在行った， $1 \sim 2$ 分で接着完了後, balloon cathe-

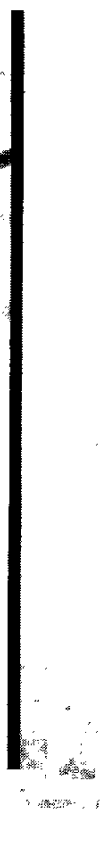

B: Inflated Fogarty catheter (right) and balloon catheter made of

ter 在縮小拔去し，へパリン加生食水で内腟洗桬，液漏出 の有無など物合部の状態を確諗の上，小孔を接着剂をたは 1 点縫合により閉鎖して血流を再開させた。大腿動脈吻合 時は，小孔のかわりに小側枝より cathctcr 捙入を行った。 血流遮断時間は平均 5 分であった(Fig. 2).

\section{2. 自家静脈片移植術}

大腿静脈㧍よび大伏在静脈 (外径 $3 \sim 4 \mathrm{~mm}$ ) 孝，小側枝を 含めて 25〜 40 mmの長さにわたり採取し，自家静脈片とし た。次に総頸動脈を露出し，血流遮断後，20 30 $\mathrm{mm}$ の動 脈片を切除してをこに静脈片を移植した. Balloon cathcter は静脈片の 1 小枝加以挿入し, 最初遠位侧を動脈端々吻合

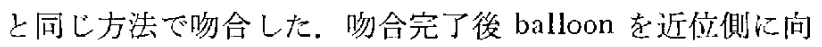
けて挿入し，近位倒の静脈片と動脈の端々吻合を行った。 動脈と静脈の口径差が小さい例では, balloonの膨脤の調 節で適合させることができ，美の大きい例は動脈端の斜位 切断, 補助䋖切開, 静脈端の folding で処理できた。吻合 完了後 balloon cathcter 拔去し, catheter 雨入口の静脈 枝加ら生食水を注入洗被した。吻合部の液漏出の有無を確 諗の上，静脈の小技を結紮閉鎖し血流を再開した，血流遮 断時間は10〜14分で, 口径比注平均5/6〜3/4で放った。 な 押，静脈片は薄く伸縮性が強いので，吻合を上り円滑に行 5ため，1〜2点の支持縫合が效果的で支ったが，約 1 分 間操作時間の延長がみられた (Fig. 3). 
1

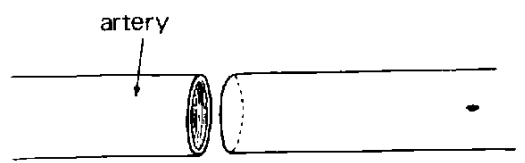

2
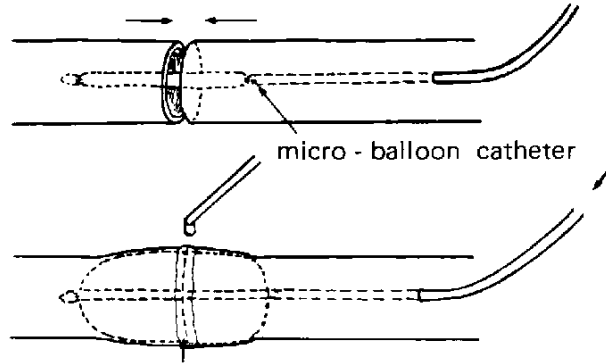

plastic adhesive

4

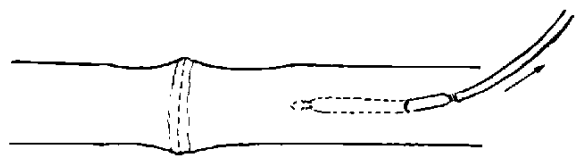

5

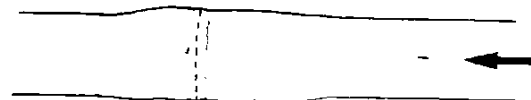

Fig. 2 Diagram of end-to-end arterial anastomosis using our micro-balloon catheter.
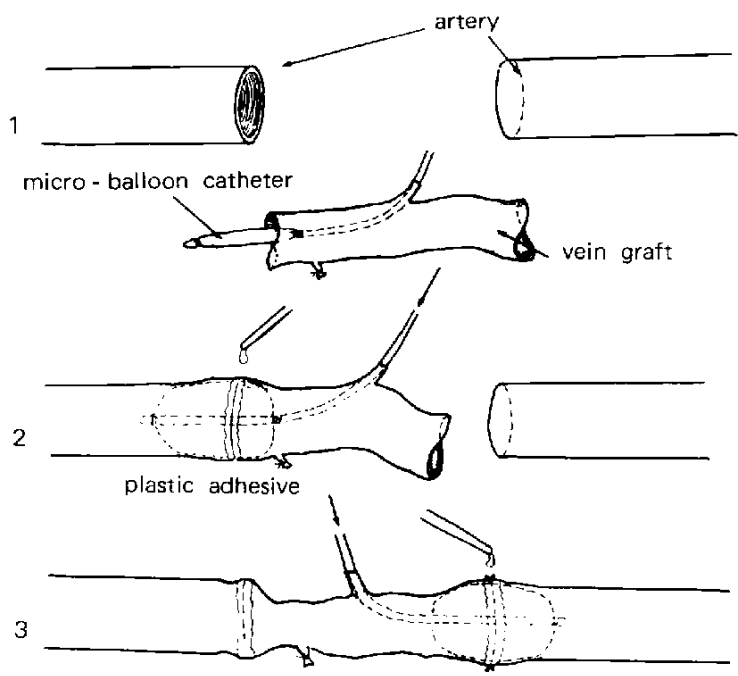

起

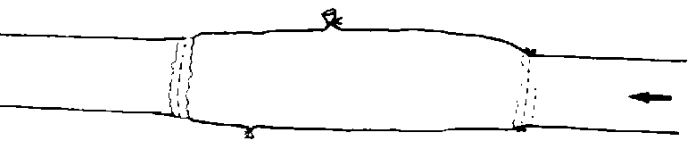

Fig. 3 Diagram of end-to-end anastomosis for vascular replacement with an autogenous vein graft.

\section{3. 人工血管移植術}

総䫫動脈索露出し, 血流遮断後, 血管を20 40 mm の長 さにわたり切除しここの部にあら加じめパリン加生食水 に浸しておいた内径 $3 \mathrm{~mm}$ のPTFEを移植した，近位側 動脈に小孔を開讨，balloon catheter を插入し，遠位側，近 位側の順に動脈端々吻合と同じ方法で吻合を行った，吻合 完了後，小孔老接着剂で，屯たは 1 点縫合を加えて閉鎖し て血流を再開させた，血流遮断時閒は8〜13分であった。 EPTFE は静脈片に比して形態保持が良く扱いやすいため， 2 点支持縫合などの補助縫合を要しなかった。

吻合終了後 $1 \sim 3$ 時問にわたって開存状態索観察したの ち閉創した。術後一定期間観察し，血管撮影を行ったのち 屠殺して，吻合部を肉眼的および組織学的に観察した。

\section{III 結 果}

開存成績：動脈端々吻合例で法，1日から6カ月の観察 で，計11動脈中10例が開存し，開存率は90.9\%であった。 閉塞例は吻合部の接合不良で出血が多く，止血できたが閉 塞が 1 週間目に確認された。自家静脈片移植例で注，1週 問から3力月の観察で, 9 血管中 8 例が開存し，開存率は 88.9\%であった. EPTFE graft の移植術は 1 週間から3 カ月の観繁で，12 血管中 8 例 $66.7 \%$ 開存率であった (Table 1).

血管撮影所見：吻合血管の中枢側穿刺により血管撮影を 行った。動脈端心吻合例では狭窄はほとんど認められなか ったが，1点縫合老加光た balloon 刺入小孔に軽度の狭窄 が認められた。自家静脈片移植例では，静脈片の拉張は， 大伏在静脈移植の1例を除いて全例に認められたが，移植 時の口径差と同程度で，経時的変化は認められなかった。 吻合部の狭窄はほとんど認められなかった (Fig. 4A). EPTFE graft による人工血管移植例で俚，開存例中 1 例に 壁の不整，1例に吻合部の狭窄が諗められた。本法に执い てむ縫合を加えた catheter 刺入小孔部の狭窄が認められた (Fig. 5A)。全例老とおして，吻合部の動脈瘤形成はなか った。

肉眼的所見：吻合血管およびその周囲の感染はなく，2

Table 1 Results of the non-suture end-to-end anastomoses

\begin{tabular}{lcc} 
Method & Follow up & Patency rate \\
\hline $\begin{array}{l}\text { arterial anastomosis } \\
(2.0-3.5 \mathrm{~mm})\end{array}$ & 1 day-6 mon. & $90.9 \%(10 / 11)$ \\
$\begin{array}{l}\text { vein graft } \\
(3.5-4.0 \mathrm{~mm})\end{array}$ & 1 week-3 mon. & $88.9 \%(8 / 9)$ \\
$\begin{array}{l}\text { EPTFE graft } \\
(3.0 \mathrm{~mm})\end{array}$ & 1 week-3 mon. & $66.7 \%(8 / 12)$ \\
\hline
\end{tabular}




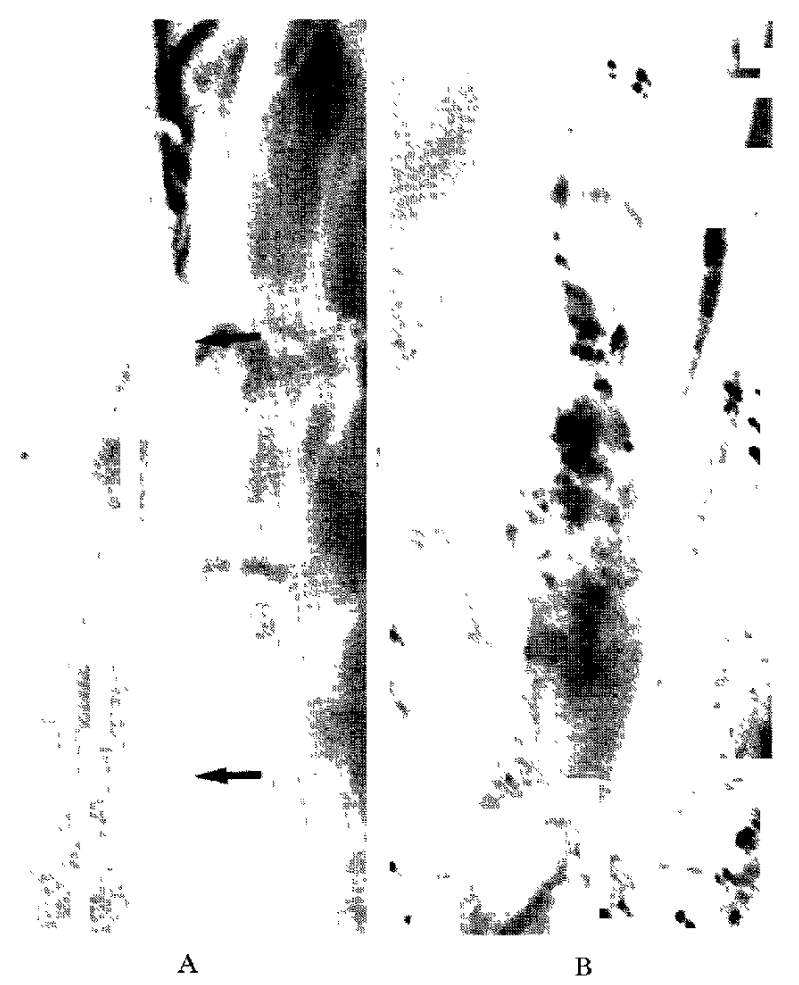

Fig. 4 A: Angiogram taken 3 months after end-to-end anastomosis with an autogenous vcin graft. Arrows show anastomosed portions without stenosis. B: The anastomosed portion of artery (lower) and vein graft (upper) in operative procedurc.

週間を経過した例では，吻合部は接着剤を含めて結合織で 被われ，血管内腔面法吻合端に $0 \sim 0.3 \mathrm{~mm}$ の部分的開隙 をみたが，接着剤の腔内迷入はなく，吻合部の間隙は平滑 な内膜で被われていた，吻合部また他部位の動脈瘤形成 は認められなかった (Fig. 4B)。

組織学的所見：HE 染色末たはSEM に上る組織学的検 䚯では，1力月以上経過した〈工血管では 2 カ月経過し た）例では，吻合部法仮性内膜の形成抒よび軽度の肥厚が 誌められるが，最内層は一層の内皮細胞で被われて㧍り， 血栓の形成法認められな加った。外膜側は，接着殽を含め て廖原線維で被われて强化されていたが，一部で周囲組織 に反応性細胞浸潤かみられた。しかし 3 力月目の組織像に は浸潤細胞の減少が認められた(Fig. 6, 7)。

\section{IV 考察}

最近の腷神経外科領域での血行再建術はその進歩がめざ ましく，自家静脈片移植術 ${ }^{3,8,15}$ や代用血管 ${ }^{14)}$ 応用が報 告されるまでに至り，いっそう操作の簡便化，時間の短縮 が要求されている，その対策の一環として，無縫合法によ

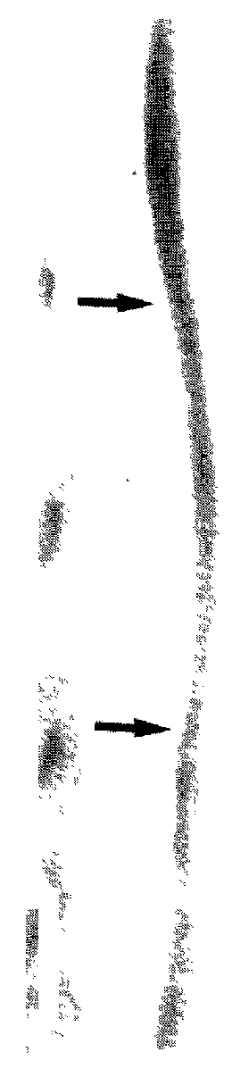

A

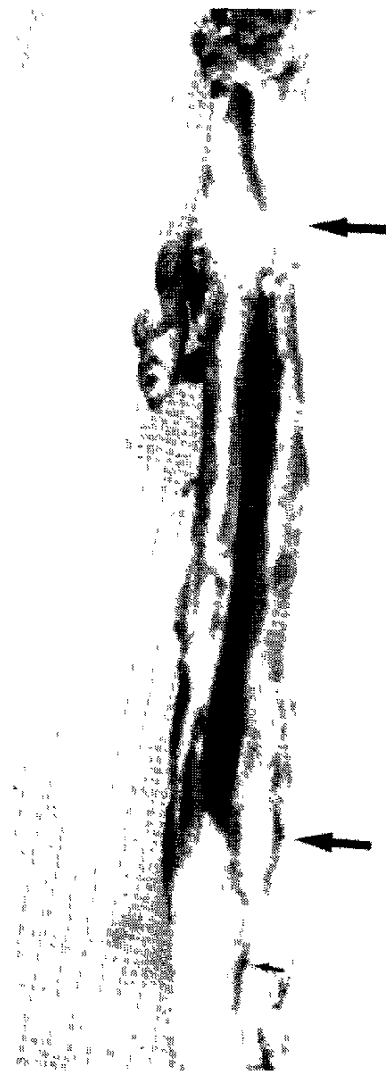

B
Fig. 5 A:Angiogram taken 3 months after replacement with an expanded polytetrafluoroethylene graft in canine carotid artery. Arrows show the portions of end-to-end anastomosis. B: Macroscopic finding of an expanded polytetrafluoroethylene graft. Arrowes show the anastomosed portions and a small incision for insertion of the catheter.

る血管移植術つ応用が指摘されている ${ }^{6)}$ ，無縫合 血管吻合 法は, 諸家の研究4,6,7,10,16,17,20,21) によりその有効性法確 認さ机ているが，本法による血管吻合法では，吻合部内腔 をいか比良好に保持するかが 1 つ要点と考光られる。こ れまでも polyethylene tube ${ }^{4\rangle}$, ring ${ }^{2,20)}$ ，種々材料に上る可 溶性支柱 ${ }^{6,12,13,17,21)}$ などの利用が研究され， $1 \mathrm{~mm}$ 前後の 細小血管汶対してむ良好な成績, 21 が報告されている。し かるに, 自家静脈片のよらに伸縮性が強く, 口径差や厚 さ，形態の異なる血管の吻合術には，動脈端々吻合術の場 合より，吻合部での内腔保持に細心の注意を払い，吻合部 の狭窄，变形や内膜損傷を防ぐ必要がある。この目的のた め, 膨脹程度を調節寸ることにより, 自由に血管腔の口经 また沙態を調節できる microballoon catheter を用いる に至った。

\section{Balloon catheter について}

脳神経外科領域にお汀る balloon catheter の発展はめざ 


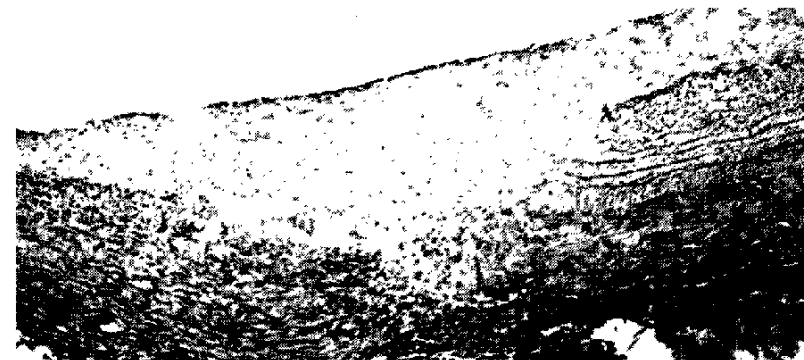

A

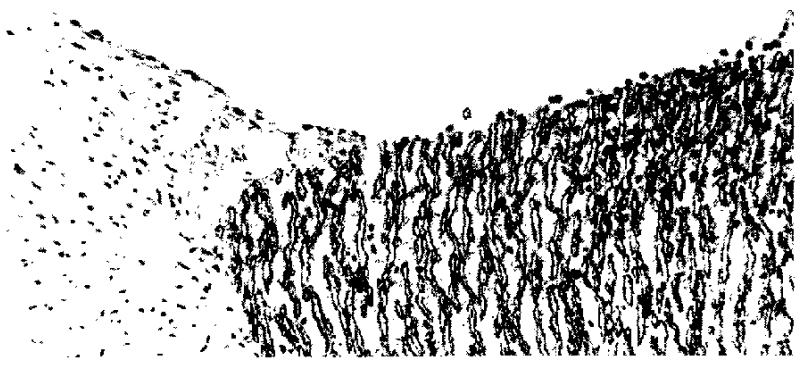

B

Fig. 6 Histological findings of the anastomosed portions. A: Autogenous vein grafting anastomosis. Vein (left) and artery (right). HE stain, $\times 40$. B: Artificial grafting anastomosis. Expanded polytetrafluoroethylene graft (right) and artery (left). Anastomosed portion is smoothly covered with endothelium. HE stain, $\times 100$.

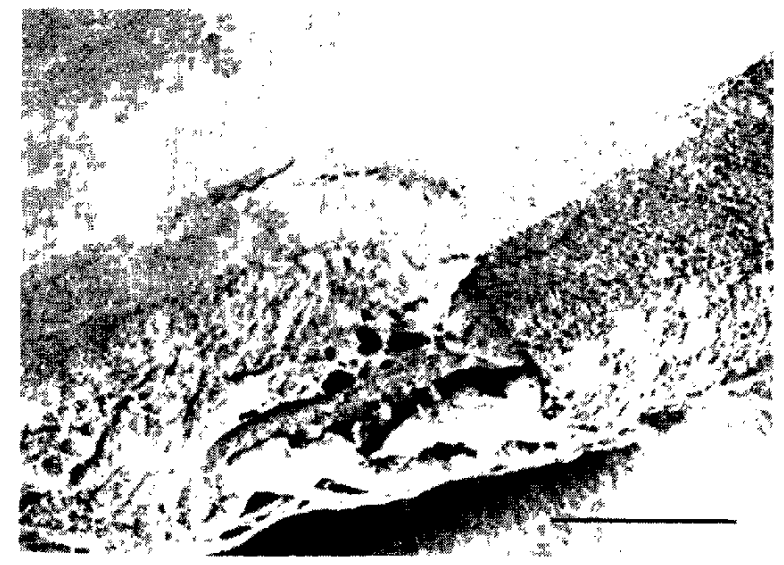

Fig. 7 Scanning electronmicroscopic findings of artificial graft anastomosis. Expanded polytetrafluoroethylene graft is shown in the right. Anastomotic portion is smoothly covered with intima and endothelium. $B a r=0.5 \mathrm{~mm}$.

ましく, embolization ${ }^{1>}$ ஓ superselective angiography な ど広く応用されている ${ }^{2,18}$ が，血管吻合への利用は非常に

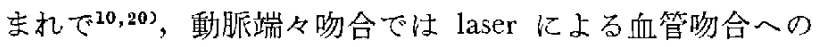

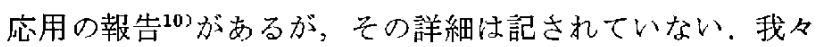
は latex 製の薄肉 tube (外径0.4 2.0 mm) 在作製 L, poly- ethylene tube (外径0.3 2.0 mm)を㧴入して軸とした microballoon catheter 作製した。 Latex balloon の両端 は, polyethylene tube に固定した Fogarty catheter type の balloon catheter $\llcorner, 一$ 端老 free $\iota し た$ balloon catheter 字作製して比較検討した。その絬果，Fogarty catheter type $\sigma$ balloon は，長軸に垂直方向への膨脤が打るなた め，長朝に垂值および平行方向に膨脹する一端 free oballoonに比し，紡錘形の一定した形態を得ることができ，吻 合口径の調節加容易で，血管の sliding， slip out や内膜損傷 が少なく吻合部を固定でき，血管吻合に優れていた，口径 差のない場合は，吻合部が balloonの中央にくるように位 置づけるが，几径差のある例で恃，細い血管側に balloon の中央が等る位置で膨脹させると，吻合折管の slip out 防止できる，血管の内翻が認められないのも本法の長所で ある。

\section{2. 補助縫合について}

無程合吻合法の技術をいっそら簡便化寸ることができる 加否かをみるため，(1)補助縫合をまったく行わない例， (2)吻合雨端に各々 2 針縫合を加えた例，打上び(3)一端のみ に補助縫合を加光た例について，それぞれの開存率，操作 難易度，および操作時間を検討した。その結果，自家静脈 移植例では開存率に差は諗められず，操作時閒は1〜2分 延应したが，技術的には容易であり，補助縫合は有效であ った，EPTFEでは開存率，扔よび技術的にも差はなく，操 作時間が延長する補助桻合は必要としなかった。

\section{3. 自家静脈片移植術について}

Catheterは静脈片の小側枝断端加施入したため, catheter 挿入用補助切開孔を要しなかった。京た，口径差の大 きい場合流，余㮃部分を折り返す folding 法，口径の小さ 以血管索斜切断する方法，補助縦切開”加える方法が行 われたが，いずれも balloon catheter が利用できた。

\section{4. 人工血管移植術について}

人工血管移植術汇抒讨るEPTFEの良好な開存性は広く 認められ，多方面で利用されているが，無縫合吻合法によ

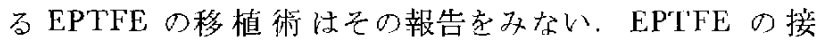
着剂による接着性注良好で，組織反态は縫合に上る吻合法 上変わらず，十分に応用できるものと思われる，技術的に は向管形態の保持, およびある程度の硬度が得られるため， 自家静脈片に比して操作加容易で，補助縫合も必要としな かった，動脈端々吻合や自家静脈片移植例の場合，急性期 の開存例は衤期観察によっても開存しているのに比べ， EPTFE では，急性期開存例です 1 週間から20月間で 3 例 閉塞して扣り，術後 1 週間から20日間がもっとも狭窄をき たしやすく”，したがって，抗血栓剂の使用の必要性が示 唆される. 


\section{V 結 語}

口径差や血管性状の違いなどの問題を有する静脈片や人 工血管の移植に対して，血管内腔保持が自由に調節できる よう balloon catheter 存用い，接着剂による無縫合血管端々 吻合法の応用を，動物実験にて試みた，動脈端々吻合術で は $290.8 \%$ ，静脈片移植術では $88.9 \% ，$ 怙よび人工血管移植 術で住 $66.7 \%$ の開存率老得た。血管撮影，肉眼的・組織学 的検討を加えてその特徽を報告したが，人工血管の無縫合 吻合法の報告はなく，新しい試みである。

\section{文献}

1) Drun G, Lacour P, Caron JP: Balloon arterial catheter techniques in the treatment of artcrial intracranial disease, in Krayenbühl $\mathbf{H}(e d)$ : Advance and Technical Standard in Neurosurgery, vol 4. Wien, Springer-Verlag, 1977, pp 121-145

2) Dotter CT, Rosch J, Judkin MP: Transluminal dilatation of atherosclerotic stenosis. Surg Gynecol Obstet 127: 794-798, 1968

3) Favaloro RG: Saphenous vein graft in the surgical treatment of coronary artery discase. Operative technique. $J$ Thorac Cardiovase Surg 58: 178-185, 1969

4) Hafner CD, Fogarty TJ, Cranley JJ : Nonsutuer anastomosis of small arteries using a tissue adhesive. Surg Gynecol Obstet 116: 417-421, 1963

5) Hatanaka M, Suzuki J, Onuma T: A soluble internal splint for vessels about $1 \mathrm{~mm}$ in external diameter in experimental vascular anastomosis. Abstracts of Short Papers section 20, the World Congress of Angiology. Tokyo, 1976, $216 \mathrm{pp}$

6) 畑中光昭：無繾合細小血管吻合法一外径 $1 \mathrm{~mm}$ 前後の血 管吻合法について二。白外会誌 $79 ： 1324-1334 ， 1978$

7) Hall RJ, Colonel L, Khouri EM, Gregg DE: Coronaryinternal mammary anastomosis in dogs. Surgery 50: 560567,1961

8) Twabuchi $T$, Kudo $T$, Hatanaka $M$, Oda $N$, Maeda $S$ : Vein graft bypass in treatment of giant aneurysm. Surg Neurol 12:463-466, 1979

9) 石丸 新，平山啓三，友成正紀，藤原靖之，古川欽一，
高橋雅俊，蜂谷哲也，俈夕 弘：EPTFE人工血管を用、 た小口径静眽移植に抬ける脱線維素醭素の投与とその効果 一Batroxobin の皮下投与法による試み一，脈管学19:7176,1979

10) Jain KK: Sutureless microvascular anastomosis using a Neodymium-YAG laser. J Microsurg 1: 436-439, 1980

11) Lougheed WM, Marchall BM, Hunter M: Common carotid to intracranial internal carotid bypass venous graft; Technical note. $J$ Neurosurg 34: 114-118, 1971

12）大西健二：無縫合細小血管吻合法の新しい手技に関す る研焭。 日外会誌 $76: 592-601,1975$

13）小沼武英：無縫合細小血管吻合法の開拓一溶解性 支持 管と接着剂老用いて一。目外会誌 $77: 777-792,1976$

14) Story JL, Brown WE, Eidelberg E, Arem KV, Stewart JR: Cerebral revascularization; Proximal carotid to distal middle ccrebral artery bypass with a synthetic tube graft. Neurosurgery 3: 61-65, 1978

15) Spetzler RF, Rhodes RS, Roski RA, Likavec MJ: Subclavian to middle cerebral artery saphenous vein bypass graft. $J$ Neurosurg 53: 465-469, 1980

16) Smith $\mathrm{S}:$ A soluble rod as an aid to vascular anastomosis: An experimental study. Arch Surg 41: 1004-1007, 1940

17) Suzuki J, Onuma T: A soluble splint for experimental vascular anastomosis. $J$ Neurosurg $35: 355-356,1971$

18）高雄哲郎，加藤量平，中井姜雄，内木研一，福田 膂, 矢野 孝, 永田昌久, 数井秀器, 小林正治, 寺沢利昭 : Dotter's catheter の使用経験，脈管学 $19: 789-795,1979$

19) Weiss EW, Lam CR: Tantalum tube in the nonsuture method of blood vessel anastomosis. Am J Surg 80: 452-456, 1950

20) Weisberg D, Schwartz P, Goetz RH: Nonsuture end to side anastomoses of small blood vessel. Surg Gynecol Obstet 123: 341-346, 1966

21) Yamagata $S$, Handa $H$, Taki W, Yonekawa $Y$, Ikada Y, Iwata H: Experimental nonsuture microvascular anastomosis using a soluble PVA tube and plastic adhesive. $J$ Microsurg 1 : 208-215, 1980

〔別刷請求先： $\overline{0} 034$ 青森県十和田市西十二番町14-8，十和 田市立中央病院脳神経外科，畑中光昭 